\title{
Fecundity, body size and population dynamics of Chrysomya albiceps (Wiedemann, 1819) (Diptera: Calliphoridae)
}

\author{
Riback, TIS. and Godoy, WAC.* \\ Departamento de Parasitologia, Instituto de Biociencias, Universidade Estadual Paulista - UNESP, \\ Distrito de Rubião Junior, CEP 18618-000, Botucatu, SP, Brazil \\ *e-mail: wgodoy@ibb.unesp.br \\ Received September 30, 2005 - Accepted May 10, 2006 - Distributed February 29, 2008
}

(With 6 figures)

\begin{abstract}
In this study, the seasonal variation of fecundity, wing and tibia length were investigated in natural populations of Chrysomya albiceps (Wiedemann, 1819) in an attempt to determine the changes in life history of the species as a function of seasonality. A relative constant temporal trajectory was found for fecundity, wing and tibia length over twentyfour months. Positive correlations between fecundity and wing size, fecundity and tibia size and wing and tibia sizes were observed. The implications of these results for population dynamics of C. albiceps are discussed.
\end{abstract}

Keywords: Calliphoridae, fecundity, population dynamics, Chrysomya albiceps.

\section{Fecundidade, tamanho corpóreo e dinâmica populacional de Chrysomya albiceps (Wiedemann) (Diptera: Calliphoridae)}

\begin{abstract}
Resumo
Neste estudo, a variação sazonal da fecundidade, comprimentos de asa e tíbia foram investigadas em populações naturais de Chrysomya albiceps (Wiedemann, 1819) como uma forma de determinar as variações bionômicas da espécie em função da sazonalidade. Uma trajetória temporal constante foi encontrada para fecundidade, comprimentos de asa e tíbia durante vinte e quatro meses. Correlações positivas entre fecundidade e comprimento de asa, fecundidade e comprimento de tíbia e comprimentos de asa e tíbia foram observadas. As implicações destes resultados para a dinâmica populacional de C. albiceps foram discutidas.
\end{abstract}

Palavras-chave: Calliphoridae, fecundidade, dinâmica de populações, Chrysomya albiceps.

\section{Introduction}

Chrysomya albiceps (Wiedemann, 1819) is a blowfly originary from the Southern Palaeartic Region, North Africa Eastwards to Northwest India, throughout Africa, including Afrotropical Islands of Aldabra, Cape Verde, Madagascar, Mauritius, Réunion, Rodriguez, St. Helena, Seychelles and Socotra (Zumpt, 1965; Baumgartner and Grennberg, 1984; Smith, 1986). This species was found in South America around 1975, together with two other species, C. putoria (Wiedemann, 1830) and C. megacephala (Fabricius, 1794). These species rapidly dispersed throughout the continent, with C. megacephala reaching the United States (Greenberg, 1988; Wells, 1991).

The Chrysomya invasion has apparently caused the displacement of Cochliomyia macellaria (Fabricius, 1775), a species native to the Americas (Guimarães et al., 1979; Prado and Guimarães, 1982; Greenberg and Szyska, 1984). Chrysomya albiceps is a facultative predator during larval stage, and some investigations have suggested that it has a stronger impact than other blowfly species, attacking third instar larvae of Cochliomyia macellaria (Faria et al., 1999; Faria and Godoy, 2001). Besides being a predator, C. albiceps also acts as a cannibal through the larval stage (Ullyett, 1950; Faria et al., 2004a).

Exotic species introduction, such as the one which occurred with $C$. albiceps, frequently produce complex interactions at the ecological and genetic levels (Pimentel, 1993; Brown, 1993). Among the main biological factors, dynamic behaviour is an important component for the assessment of relevant demographic aspects concerning biological invasions (Hengeveld, 1989). However, dynamic behavior usually depends on factors associated to demography, such as growth rate and carrying capacity (Hengeveld, 1989; Lande, 1993; Uchmanski, 1999). The values of demographic parameters associated with population growth may exhibit high variation among different species and populations (Gotelli, 1995). The causes of variation are usually diverse and depend on the environment and/or biological attributes of each organism (Brewer, 1994). 
Among the biological parameters directly associated to growth rate in blowflies, fecundity plays an important role in population persistence since it determines the population growth potential (Von Zuben et al., 1993; Reis et al., 1996; Godoy et al., 1996). Studies focusing on dynamic behavior of blowflies analysed by mathematical models have revealed that the stability of population equilibrium depends essentially on survival and fecundity (Godoy et al., 1996; Reis et al., 1996; Teixeira et al., 1998). Using bifurcation theory to perform a parametric sensitivity analysis, Godoy et al. (1996) observed that the variation of fecundity and survival produces qualitative changes in the population dynamics of $C$. macellaria, C. megacephala and $C$. putoria. The three species exhibited changes from stable equilibrium to a two-point limit cycle (Godoy et al., 1996). However, the increase of fecundity values in C. megacephala promoted successive changes in dynamics behavior, starting with two-point limit cycle, going through four-point limit cycle and then reaching chaos (Godoy et al., 1996). The values used in these simulations are apparently real in natural populations (Ullyett, 1950); nevertheless, nothing is known about the seasonal variations in fecundity and other biological characteristics such as the body size of $C$. albiceps natural populations.

Fecundity, survival, developmental rate, weight and body size are generally density-dependent characters influenced by environmental factors in insect populations (Bryant, 1977; Reis et al., 1994; Ribeiro et al., 1995; James and Partridge, 1998; Rosa et al., 2004). Thus, it is important to design studies focusing on the association between bionomics and seasonality, since competitive ability has been considered different among species and populations (Ribeiro et al., 1995; Partridge et al., 1994; James and Partrigde, 1998; Reis et al., 1999).

In the present study we analyzed the seasonal variation of fecundity, wing and tibia length in natural populations of $C$. albiceps. The seasonal influence of life history parameters has been frequently studied in insects, showing a strong association between environmental variables and their effects on demography and body size in several taxonomic groups (Reigada and Godoy, 2005). Chrysomya albiceps is a species which has different characteristics if compared to other blowfly species, principally in terms of larval behavior. In blowflies, the larval stage is the most important life phase because its performance in nutritional terms can be reflected in adulthood since the interactive processes that occurred during the immature stage may be determined by exploitative larval competition (Rosa et al., 2004). The result of this can significantly influence the magnitude of parameter values, with consequences for population dynamics of the species, especially if facultative predation by an intraguild predator is taken into account, as happens with $C$. albiceps. Thus, the examination of the seasonal effects on its fecundity as well as body size can bring important informations about its dynamics, permitting comparisons with recent results of investigations of this nature focused on non predator species, such as the recent study carried out by Reigada and Godoy (2005) in C. megacephala.

The objective of this study then was to investigate the seasonality of fecundity and body size expressed by the wing and tibia length during two years, as an attempt to understand the population dynamic of C. albiceps.

\section{Material and Methods}

Specimens of $C$. albiceps were collected monthly from April (2002) to March (2004) in the vicinities of the campus of São Paulo State University in Botucatu, São Paulo, Brazil. A total of 300 blowfly females were collected over the investigated period. Adult flies were maintained under laboratory conditions in cages $(30 \mathrm{~cm} \times 30 \mathrm{~cm} \times 30 \mathrm{~cm})$ at $25 \pm 1{ }^{\circ} \mathrm{C}$ and fed water and sugar ad libitum. Adult females were fed fresh liver to permit complete development of the gonotrophic cycle (Linhares, 1988). Females were dissected and the number of eggs was recorded. Body size was estimated by measuring right wing and tibia length of the flies. Seasonal fecundity and wing and tibia length were compared by one-way ANOVA. Pearson's coefficient was used to analyse the correlation between life-history parameters. Mean monthly temperatures for Botucatu area were obtained from Meteorological Station of São Paulo State University in Botucatu, São Paulo, Brazil.

\section{Results and Discussion}

Chrysomya albiceps exhibited a relatively stable temporal trajectory for fecundity, wing and tibia length during twenty four months (Figures 1-3). Correlations between fecundity and temperature, wing length and temperature, and tibia length and temperature were nonsignificant. A moderate positive correlation between wing length and fecundity $(r=0.56, p<0.05)$, and tibia length and fecundity $(\mathrm{r}=0.55, \mathrm{p}<0.05)$ was also detected (Figures 4,5 ). The analysis of correlation between wing and tibia lengths (Figures 6) showed a strong positive correlation between the two variables $(r=0.67$, $\mathrm{p}<0.05)$. These two variables are generally well correlated in flies (Reigada and Godoy, 2005). However, in certain taxonomic groups the wing size investment can be higher in response to flight requirement or sexual selection (Reis et al., 1994; Hasson and Rossler, 2002).

The weak oscillations found for fecundity, wing and tibia length indicate that the three characteristics were maintained relatively constant over the two years, suggesting practically no impact of the seasonality on these variables. Considering the usual strong correlation between body size and fecundity found in most Diptera (So and Dudgeon, 1989a,b; Armbruster and Hutchinson, 2002; Bochdanovits and De Jong, 2003), the results obtained in this study are surprising, since the correlations were moderate, but perhaps stem from rather restricted variation in body size in this tropical location. 


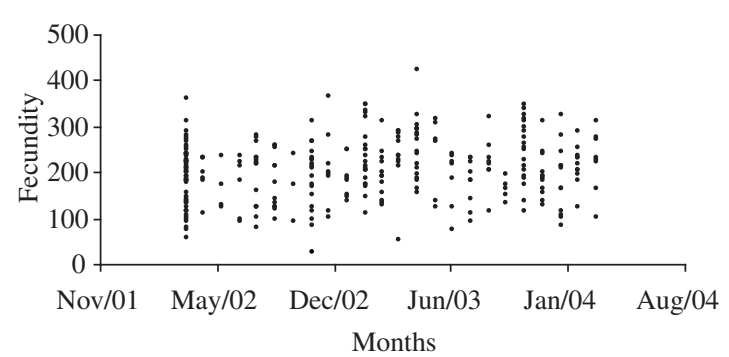

Figure 1. Seasonal variation of fecundity in Chrysomya albiceps.

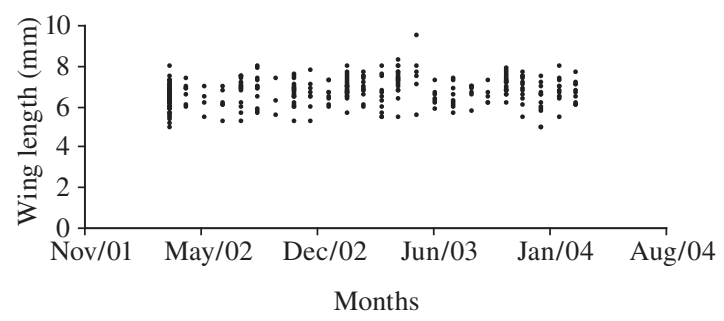

Figure 2. Seasonal variation of wing length in Chrysomya albiceps.

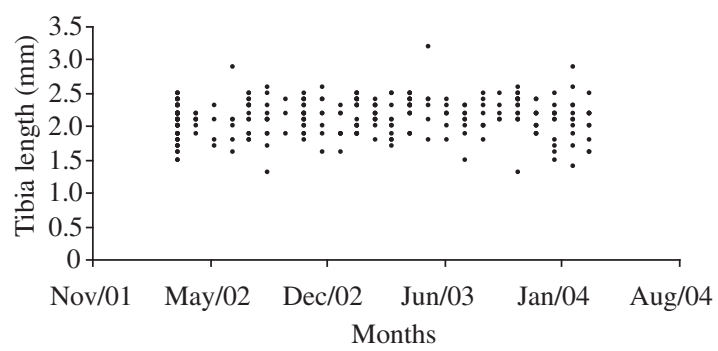

Figure 3. Seasonal variation of tibia length in Chrysomya albiceps.

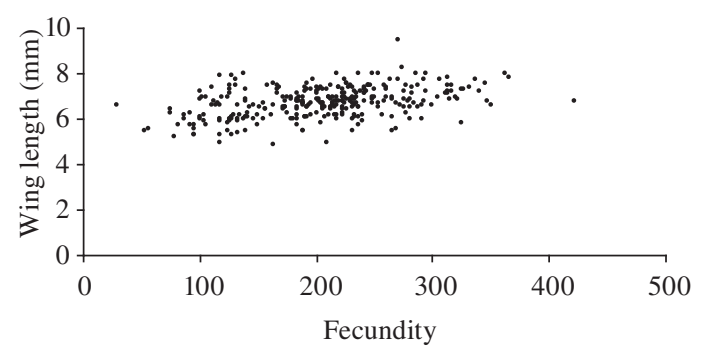

Figure 4. Correlation between wing length and fecundity.

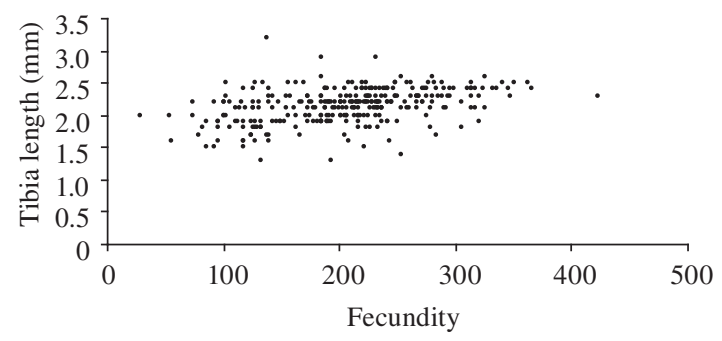

Figure 5. Correlation between tibia length and fecundity.

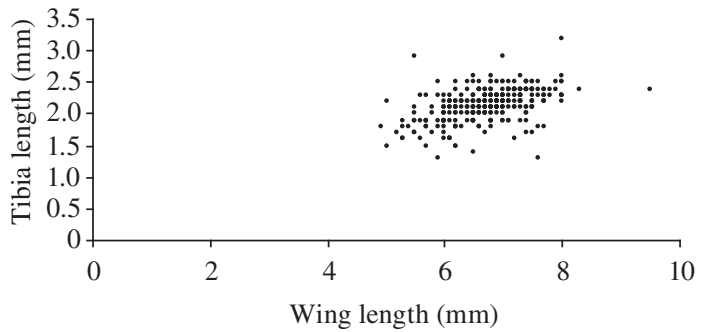

Figure 6. Correlation between wing and tibia length.

Seasonal fluctuations in the physical environment may affect the resource base, which the organisms use to feed from (Hannon and Ruth, 1997). The temporal oscillations in blowflies have been studied frequently to analyze the association between environmental seasonal factors and abundance of adults (Linhares, 1981; Mendes and Linhares, 1993; Schnack and Mariluis, 1995; Wall et al., 2001).

Among all environmental factors, temperature has been considered essential as it can directly influence the population dynamics of insects, such as the population growth of $M$. domestica, particularly in equatorial and tropical zones, where there are high densities of this species (Levine and Levine, 1991). The effects of temperature on the development and survival of insects have been extensively investigated (Roy et. al., 1991; Gilbert and Raworth, 2000; Bhattacharya and Banerjee, 2001; Nteletsana et al., 2001; Thind and Dunn, 2002). The rates of physiological processes are strongly influenced by body temperature (Hochachka and Somero, 1984; Prosser, 1986) as thermal sensitivity can profoundly affect the behaviour, ecology and evolution of ectotherms (Heinrich, 1981; Huey, 1982).

Although some studies have been designed to investigate population behavior in response to temperature, they have focused specifically on geographic variation, genetic divergence and natural selection, considering adult census (Anderson, 1972; Huey et al., 1991; Partridge et al., 1994; Santos et al., 1997), differently from the present investigation, which focused on the census of life-history characteristics. It is possible that in other blowfly species, the temperature affected much more the abundance of adult populations than was observed in this study. Even focusing on adults, significant differences have been found among the principal Calliphoridae species, for example, Lucilia eximia (Wiedemann, 1819) that apparently is able to maintain a more stable population size that other calliphorid species, when facing environmental disturbances (Linhares,1981; Moura et al., 1997).

Perhaps from the results found in this investigation two important questions could emerge. Do the Brazilian environmental conditions induce the life-history values to exhibit this result? What influences on life history would be expected in C. albiceps origin regions? The results observed in this study showed that the fecundity is maintained relatively constant during 24 months, in spite of its spectrum of variability. However, the number of 
eggs found over the period analyzed was slightly higher than $C$. megacephala, another species with fecundity recently censused (Reigada and Godoy, 2005). This result indicates quantitative differences in spite of the similar pattern population dynamics found for the two species. In addition, the comparison of the seasonal fecundity obtained in this investigation with the results observed by Reigada and Godoy (2005), indicates a difference in terms of variability of the fecundity between the two species. Chrysomya albiceps exhibited fecundity values that oscillated approximately between 30 and 400, against the values observed in $C$. megacephala, which oscillated between 130 to 270 (Reigada and Godoy, 2005).

We believe that the higher variability detected in C. albiceps could be attributed to the facultative larval predation, since the gain obtained consuming prey is occasional, leading the predator to eventually convert prey into offspring. It is possible that the apparent difference may be due to alternative food sources of $C$. albiceps as both intraguild predator and cannibal; behaviors, which seem important in terms of nutritional ecology and population dynamics (Polis et al., 1989; Faria et al., 1999, 2004b; Rosa et al., 2004).

In conclusion, in spite of the environmental condition producing some influence on the fecundity of $C$. albiceps, the interspecific interactions probably interfere more expressively on this demographic parameter. Chrysomya albiceps is currently one of the most abundant blowfly species in Brazil and we believe that the present results explain at least in part the success of the species following the occurrence of the biological invasion.

Acknowledgments - TISR has been supported by scholarship from Fapesp (02/02050-0). WACG has been partially supported by a research fellowship from Conselho Nacional de Desenvolvimento Científico e Tecnológico. The authors are grateful to the anonymous reviewers for pertinent suggestions.

\section{References}

ANDERSON, WW., 1972. Genetic divergence in body size among experimental populations of Drosophila pseudoobscura kept at different temperatures. Evolution, vol. 27, no. 2, p. $278-284$.

ARMBRUSTER, P. and HUTCHINSON, RA., 2002. Pupal Mass and Wing Length as Indicators of Fecundity in Aedes albopictus and Aedes geniculatus (Diptera: Culicidae). J. Med. Entomol., vol. 39, no. 4, p. 699-704.

BAUMGARTNER, DL. and GREENBERG, B., 1984. The genus Chrysomya (Diptera: Calliphoridae). J. Med. Entomol., vol. 21, no. 1, p. 105-113.

BHATTACHARYA, B. and BANERJEE, TC., 2001. Factors affecting egg-laying behaviour and fecundity of Callosobruchus chinensis (L.) (Coleoptera: Bruchidae) infesting stored pulses. Orient. Ins., vol. 35, p. 373-386.

BOCHDANOVITS, Z. and DE JONG G., 2003, Temperature dependent larval resource allocation shaping adult body size in Drosophila melanogaster. J. Evol. Biol., vol. 16, no. 6, p. $1159-1167$.
BREWER, R.,1994. The science of ecology. Saunders College Publishing, $2^{\text {nd }}$ ed., Ft Worth, USA, 773 p.

BRYANT, EH., 1977. Morphometric adaptation of housefly, Musca domestica L. in the United States. Evolution, vol. 31, no. 3 , p. $580-596$.

BROWN, MW.,1993. Population dynamics of invading pests: factors governing success, In KIM, KC. and MC-PHERON, BA. (eds.), Evolution of insect pests: Patterns of variation. John Wiley \& Sons, New York, p. 203-218,

FARIA, LDB., ORSI, L., TRINCA, LA. and GODOY, WAC., 1999. Larval predation by Chrysomya albiceps on Cochliomyia macellaria, Chrysomya megacephala and Chrysomya putoria. Ent. Exp. App., vol. 90, no. 2, p. 149-155.

FARIA, LDB. and GODOY, WAC., 2001. Prey choice by facultative predator larvae of Chrysomya albiceps (Diptera, Calliphoridae). Mem. Inst. Oswaldo Cruz. vol. 96, no. 6, p. $875-878$.

FARIA, LDB., TRINCA, LA. and GODOY, WAC., 2004a. Cannibalistic behavior and functional response in Chrysomya albiceps (Diptera: Calliphoridae). J. Insect Beh. vol. 17, no. 2, p. 251-261.

FARIA, LDB., GODOY, WAC. and REIS, SF., 2004b. Larval predation on different instars in blowfly populations. Braz. Arch. Biol. Techn., vol. 47, no. 6, p. 887-894.

GILBERT, N. and RAWORTH, DA., 2000. Insects and temperature-differential effects of experimental conditions on growth and development. Can. Entomol., vol. 132, no. 4, p. 539-549.

GREENBERG, B. and SZYSKA, ML.,1984. Immature stages and biology of fifteen species of peruvian Calliphorid (Diptera). Ann. Ent. Soc. Am., vol. 77, p. 88-517.

GREENBERG, B., 1988. Chrysomya megacephala (F.) (Diptera: Calliphoridae) collected in North America and notes on Chrysomya species present in the New World. J. Med. Entomol., vol. 25, no. 3, p. 199-200.

GODOY, WAC., VON-ZUBEN, CJ., REIS, SF. and VON ZUBEN, FJ., 1996. Dynamics of experimental populations of native and introduced blowflies (Diptera: Calliphoridae): mathematical modelling and the transition from asymptotic equilibrium to bounded oscillations. Mem. Inst. Osw. Cruz, vol. 91 , no. 5 , p. 641-648.

GOTELLI, NJ., 1995. A primer of ecology, Sinauer Associates Inc., MA, USA, 206 p.

GUIMARÃES, JH., PRADO, AP. and BURALLI, M., 1979. Dispersal and distribution of three newly introduced species of Chrysomya Robineau-Desvoidy in Brasil (Diptera, Calliphoridae). Revta. Bras. Entomol. vol. 23, no. 4, p. 245-255.

HANNON, B. and RUTH, M.,1997, Modelling dynamic biological systems. Springer, N.Y.

HASSON, O. and ROSSLER, Y., 2002. Character-specific hoemostasis dominates fluctuating asymmetries in the medfly (Diptera: Tephritidae). Florida Entomologist, vol. 85, no. 1, p. 73-82.

HEINRICH, B., 1981. Ecological and evolutionary perspectives. In B. HEINRICH (Ed.) Insect thermoregulation. John Wiley \& Sons, NY., 236-302 p. 
HENGEVELD, R.,1989. Dynamics of biological invasions, Chapman and Hall, London, $160 \mathrm{p}$.

HOCHACHKA, PW. and SOMERO, GN., 1984. Biochemical Adaptation, Princeton University Press. Princeton, NJ, 537 p.

HUEY, RB.,1982. Temperature, physiology, and the ecology of reptiles. In C. GANS, and F. H. POUGH, (eds.) Biology of the Reptilia. Academic Press, Cambridge, UK. 25-91 p.

HUEY, R. B., PARTRIDGE, L. and FOWLER, K., 1991. Thermal sensitivity of Drosophila melanogaster responds rapidly to laboratory natural selection. Evolution, vol. 45, no. 3, p. 751-756.

JAMES, A. C. and PARTRIDGE, L.,1998. Geographic variation in competitive ability in Drosophila melanogaster. Am. Nat., vol. 151 , no. 6 , p. 530-537.

LANDE, R., 1993. Risks of population extinction from demographic and environmental stochasticity and random catastrophes. Am. Nat., vol. 142, no. 6, p. 911-927.

LEVINE, O. S. and LEVINE, MM., 1991. Houseflies (Musca domestica) as mechanical vectors of Shigellosis. Clin. Infec. Dis., vol. 13 , no. 44 , p. 688-696.

LINHARES, AX.,1981. Synanthropy of Calliphoridae and Sarcophagidae (Diptera) in the city of Campinas, São Paulo, Brazil. Revta. Bras. Entomol., vol. 25, no. 3, p. 189-215.

-, 1988. The gonotrophic cycle of Chrysomya megacephala (Diptera: Calliphoridae) in the laboratory. Revta. Bras. Entomol. vol. 32, no. 3-4, p. 383-392.

MENDES, J. and LINHARES, AX., 1993. Atratividade por iscas e estágios de desenvolvimento ovariano em várias espécies sinantrópicas de Calliphoridae (Díptera). Revta. Bras. Entomol. vol. 37 , no. 1 , p. 157-164.

MOURA, MO., CARVALHO, CJB. and MONTEIRO, ELA., 1997. A preliminary analysis of insects of medico-legal importance in Curitiba, State of Paraná. Mem. Inst. Osw. Cruz, vol. 92 , no. 2, p. 269-274.

NTELETSANA, L., SCHOEMAN, AS. and MCGEOCH, MA., 2001. Temperature effects on development and survival of the sweetpotato weevil, Cylas puncticollis Boheman (Coleoptera: Apionidae). Afr. Entomol. vol. 9, p. 49-57.

PARTRIDGE, L., BARRIE, B., FOWLER, K. and FRENCH. V., 1994, Evolution and develpment of body and cell size in Drosophila melanogaster in response to temperature. Evolution, vol. 48 , no. 4, p. 1269-1276.

PIMENTEL, D.,1993. Habitat factors in new pest invasions. In KC. KIM and BA. MCPHERON (eds.) Evolution of insect pests: Patterns of variation, John Wiley \& Sons, New York. 165-181 p.

POLIS, GA.; MYERS, CA. and HOLT, RD., 1989. The ecology and evolution of intraguild predation: potential competitors that eat each other. Ann. Rev. Ecol. Sys., vol. 20, p. 297-330.

PRADO, AP. and GUIMARÃES, JH., 1982. Estado atual da dispersão e distribuição do gênero Chrysomya RobineauDesvoidy na região neotropical (Diptera, Calliphoridae). Revta. Bras. Entomol., vol. 26, no. 3, p. 225-231.

PROSSER, CL., 1986. Adaptational Biology: Molecules to Organisms. John Wiley \& Sons, NY. 766 p.

REIGADA, C. and GODOY, WAC., 2005. Seasonal Fecundity and Body Size in Chrysomya megacephala (Fabricius) (Diptera: Calliphoridae). Neotr. Entomol., vol. 34, no. 2, p. 163-168.
REIS, SF., STANGENHAUS, G., GODOY, WAC., VON ZUBEN, CJ. and RIBEIRO, OB., 1994. Variação em caracteres bionômicos em função da densidade larval em Chrysomya megacephala e Chrysomya putoria (Diptera, Calliphoridae). Revta. Bras. Entomol. vol. 38, no. 1, p. 33-46.

REIS, SF., TEIXEIRA, MA., VON ZUBEN, FJ., GODOY, WAC. and VON ZUBEN, CJ., 1996. Theoretical dynamics in experimental populations of introduced and native blowflies (Diptera: Calliphoridae). J. Med. Entomol., vol. 33, no. 4, p. 537-544.

REIS, SF., ZUBEN, CJV. and GODOY, WAC., 1999. Larval aggregation and competition for food in experimental populations of Chrysomya putoria (Wied.) and Cochliomyia macellaria (F.) (Dipt. Calliphoridae). J. Appl. Entomol., vol. 123, p. 485-489.

RIBEIRO, SC., SOUZA, AM. and LOMÔNACO, C., 1995. Influência de fatores ambientais na determinação do tamanho de Musca domestica L. (Diptera: Muscidae). Revta. Bras. Biol., vol. 55, no. 4, p. 633-637.

ROSA, GS., CARVALHO, L. and GODOY, WAC., 2004. Survival rate, body size and food abundance in pure and mixed blowfly cultures. Afr. Entomol. vol. 12, p. 97-105.

ROY, R., DAS, AB. and FARKAS, T., 1991. Role of environmental thermal fluctuation in seasonal-variation of fattyacid composition of total lipid in fat-body of the cockroach, Periplaneta americana (Linn). J. Therm. Biol., vol. 16, p. 211-215.

SANTOS, M., BORASH, DJ., JOSHI, A., BOUNLUTAY, N. and MUELLER, LD., 1997. Density-dependent natural selection in Drosophila: evolution of growth rate and body size. Evolution., vol. 51, no. 2, p. 420-432.

SCHNACK, JA. and MARILUIS, JC., 1995. Status of Chrysomya blowflies (Diptera: Calliphoridae) in Argentina. J. Vec. Ecol., vol. 20, p. 189-194.

SMITH, KGV., 1986. A manual of forensic entomology. University Printing House, Oxford, 205 p.

SO, PM. and DUDGEON, D., 1989a, Variation in the life history parameters of Hemipyrellia ligurriens (Diptera: Calliphoridae) in response to larval competition for food. Ecol. Entomol., vol. 14, p. 109-166.

SO, PM. and DUDGEON, D., 1989b. Life history responses of larviparous Boettcherisca formosensis (Diptera: Sarcophagidae) to larval competition for food, including comparisons with oviparous Hemipyrellia ligurriens (Calliphoridae). Ecol. Entomol. vol. 14, p. 349-356.

TEIXEIRA, MA., VON-ZUBEN, FJ., GODOY, WAC., VON-ZUBEN, CJ. and REIS, SF., 1998. Delay density dependence at the immature stage in insects and the dynamic behavior of nonlinear difference equations. Ciênc. Cult., vol. 50, p. $268-272$.

THIND, BB. and DUNN. JA., 2002. A laboratory evaluation of a regulated airflow through wheat at four combinations of temperature and humidity on the productivity of three species of stored product mites. Exp. App. Acar. vol. 27, p. 89-102.

ULLYETT, GC., 1950. Competition for food and allied phenomena in sheep-blowfly populations. Phil.Trans. Roy. Soc. Lond., vol. 234b, p. 79-174.

UCHMANSKI, J., 1999. What promotes persistence of a single population: an individual bases model. Ecol. Mod. vol. 115, p. $227-241$. 
Riback, TIS. and Godoy, WAC.

VON-ZUBEN, CJ., REIS, SF., VAL, JBR., GODOY, WAC. and RIBEIRO, OB., 1993. Dynamics of a mathematical model of Chrysomya megacephala (Diptera: Calliphoridae). J. Med. Entomol. vol. 30, p. 443-448.

WALL, R., HOWARD, JJ. and BINDU, J., 2001. The seasonal abundance of blowflies infesting drying fish in south-west India. J. App. Ecol. vol. 38, p. 339-348.
WELLS, JD., 1991. Chrysomya megacephala (Diptera: Calliphoridae) has reached the continental United States: review of its biology, pest status and spread around the world. J. Med. Entomol., vol. 28, no. 3, p. 471-473.

ZUMPT, F., 1965. Myiasis in man and animals in the Old World. Butterworths, London, 267 p. 